\title{
ASPEK HUKUM PERLINDUNGAN TERHADAP PENUMPANG BUS DALAM MEWUJUDKAN PERLINDUNGAN KONSUMEN
}

\author{
Rabiah Z. Harahap \\ Fakultas Hukum Universitas Muhammadiyah Sumatera Utara \\ E-mail: rabiahharahap@yahoo.com
}

\begin{abstract}
Bus is the one of transportation which is often used by society. Society as passenger of bus righteously gains protection. Many of accident happens in public transportation especially bus that rises a question the important of protection for people as the accicent victim. This question is worthy to be solved because many of public transportation company ignores the passenger's right. Based on this, government shall take control with presentation of new regulation that aims protection people as consument that uses bus as public transportation.
\end{abstract}

\section{Kata Kunci: Aspek Hukum, Perlindungan, Penumpang, Bus}

\section{A. Latar Belakang}

Pengangkutan darat dengan kendaraan umum diadakan dengan perjanjian antara perusahaan angkutan umum dan penumpang atau pemilik barang. Karcis penumpang dan surat pengangkutan barang merupakan tanda bukti telah terjadi perjanjian pengangkutan dan pembayaran biaya pengangkutan. Pada sisi yang sama karcis penumpang diterbitkan atas nama (on name), artinya tidak dapat dialihkan dengan menyerahkan karcis penumpang kepada pihak lain. Surat pengangkutan barang juga diterbitkan atas nama (on name), artinya tidak dapat dialihkan kepada pihak lain.

Salah satu alat transportasi yang sering digunakan oleh masyarakat adalah bus. Penumpang bus sebagai konsumen sering dirugikan dengan adanya beberapa masalah yang terjadi misalnya keterlambatan jadwal keberangkatan, kondisi bus yang tidak layak jalan, terjadi kecelakaan bus. Pada kondisi seperti ini, maka penumpang tentu saja memerlukan perlindungan hukum untuk memastikan haknya dapat terpenuhi. Penumpang sebagai konsumen jika terjadi kecelakaan yang dialami oleh bus, hanya mendapat asuransi dari perusahaan asuransi yang diambil 
dari uang tiket penumpang, tapi dari pihak perusahaan bus tidak mendapat apaapa kecuali hanya permohonan maaf. Tentu saja banyak konsumen yang merasa hak-haknya diabaikan oleh pihak perusahaan bus, padahal konsumen berhak untuk mendapatkan lebih dari sekedar asuransi kecelakaan, karena telah membayar ongkos sesuai dengan yang ditetapkan oleh pihak perusahaan bus.

Perlindungan konsumen berkaitan dengan perlindungan hukum, sehingga perlindungan konsumen pasti mengandung aspek hukum. Materi yang mendapatkan perlindungan itu bukan sekedar fisik saja melainkan kepada hak- hak yang bersifat abstrak. Jadi perlindungan konsumen sangat identik dengan perlindungan yang diberikan hukum terhadap hak-hak konsumen. Artinya pihak perusahaan pengangkutan harus turut bertanggungjawab terhadap kerugian yang dialami oleh penumpangnya.

Penerbitan dokumen pengangkutan atas nama, ada kaitannya dengan perlindungan asuransi terhadap pemegang dalam hal terjadi musibah. Pemegang dokumen pengangkutan adalah orang yang berhak memperoleh santunan atau ganti kerugian dari pihak asuransi. Asuransi ini sendiri bertujuan untuk memberikan perlindungan hukum kepada penumpang dalam hal terjadinya kecelakaan, sedangkan kecelakaan adalah suatu kejadian tak diduga dan tidak dikehendaki yang mengacaukan proses aktivitas yang telah diatur. Kecelakaan terjadi tanpa disangka-sangka dalam sekejap mata, dan setiap kejadian terdapat empat faktor bergerak dalam satu kesatuan berantai, yakni: lingkungan, bahaya, peralatan dan manusia. Kecelakaan dapat terjadi setiap saat dan dimana saja. Kecelakaan bisa terjadi di darat, laut, dan udara tetapi umumnya terjadi pada alat transportasi atau lalu lintas dalam bentuk kecelakaan lalu lintas.

Terkait dengan masalah pengangkutan, maka menurut Muhammad (2008: 1) ada 3 (tiga) konsep pengangkutan yang perlu diperhatikan, yaitu:

1. Pengangkutan sebagai usaha (business);

2. Pengangkutan sebagai perjanjian (agreement); dan

3. Pengangkutan sebagai proses penerapan (applying process).

Selain itu, ada asas hukum pengangkutan yang merupakan landasan filosofis sebagai dasar ketentuan-ketentuan pengangkutan yang menyatakan kebenaran, 
keadilan, dan kepatutan yang diterima oleh semua pihak, kebenaran, keadilan, dan kepatutan juga menjadi tujuan yang diharapkan oleh pihak-pihak, terutama adalah pihak pengguna pengangkutan.

Sebenarnya aspek hukum transportasi tidak terlepas dari efektivitas hukum pengangkutan itu sendiri, yang secara yuridis diatur dalam Buku Ketiga KUH Perdata dan Buku Kedua KUH Dagang. Selain itu, pemerintah telah mengeluarkan kebijakan di bidang transportasi darat yaitu dengan dikeluarkannya Undangundang Nomor 22 Tahun 2009 tentang Lalu Lintas dan Angkutan Jalan (UU No. 22 Tahun 2009) sebagai pengganti Undang-undang Nomor 14 Tahun 1992, serta Peraturan Pemerintah Nomor 41 Tahun 1993 tentang Angkutan Jalan (PP No. 41 Tahun 1993) yang masih tetap berlaku, walaupun merupakan peraturan pelaksana dari Undang-undang Nomor 14 Tahun 1992.

Berdasarkan Pasal 2 UU No. 22 Tahun 2009, disebutkan bahwa asas penyelenggaraan lalu lintas, terdiri dari: (1) asas transparan; (2) asas akuntabel; (3) asas berkelanjutan; (4) asas partisipatif; (5) asas bermanfaat; (6) asas efisien dan efektif; (7) asas seimbang; (8) asas terpadu; dan (9) asas mandiri. Selanjutnya dalam Pasal 3 UU No. 22 Tahun 2009, disebutkan pula bahwa tujuan dari lalu lintas dan angkutan jalan, adalah:

1. terwujudnya pelayanan lalu lintas dan angkutan jalan yang aman, selamat, tertib, lancar, dan terpadu dengan moda angkutan lain untuk mendorong perekonomian nasional, memajukan kesejahteraan umum, memperkukuh persatuan dan kesatuan bangsa, serta mampu menjunjung tinggi martabat bangsa;

2. terwujudnya etika berlalu lintas dan budaya bangsa; dan

3. terwujudnya penegakan hukum dan kepastian hukum bagi masyarakat.

UU No. 22 Tahun 2009 diharapkan dapat membantu mewujudkan kepastian hukum bagi pihak-pihak yang terkait dengan penyelenggaraan jasa angkutan, baik itu pengusaha angkutan, pekerja (sopir/pengemudi), serta penumpang. Secara operasional kegiatan penyelenggaraan pengangkutan dilakukan oleh pengemudi atau sopir angkutan dimana pengemudi merupakan pihak yang mengikatkan diri untuk menjalankan kegiatan pengangkutan atas perintah pengusaha angkutan atau pengangkut. Pengemudi dalam menjalankan tugasnya 
mempunyai tanggung jawab untuk dapat melaksanakan kewajibannya yaitu mengangkut penumpang sampai pada tempat tujuan yang telah disepakati dengan selamat, artinya dalam proses pemindahan tersebut dari satu tempat ke tempat tujuan dapat berlangsung tanpa hambatan dan penumpang dalam keadaan sehat, tidak mengalami bahaya, luka, sakit maupun meninggal dunia. Sehingga tujuan pengangkutan dapat terlaksana dengan lancar dan sesuai dengan nilai guna masyarakat.

Kenyataannya masih sering pengemudi angkutan melakukan tindakan yang dinilai dapat menimbulkan kerugian bagi penumpang, baik itu kerugian yang secara nyata dialami oleh penumpang (kerugian materil), maupun kerugian yang secara immateril, seperti kekecewaan dan ketidaknyamanan yang dirasakan oleh penumpang. Misalnya saja tindakan pengemudi yang mengemudi secara tidak wajar, dalam arti saat menjalani tugasnya pengemudi dipengaruhi oleh keadaan sakit, lelah, meminum sesuatu yang dapat mempengaruhi kemampuannya mengemudikan kendaraan secara ugal-ugalan, sehingga dapat menyebabkan terjadinya kecelakaan dan penumpang yang menjadi korban.

Kenyataan seperti ini tentunya sangat merugikan para penumpang sebagai konsumen dari jasa pengangkutan. Oleh sebab itu, para pemilik (penyelenggara) jasa pengangkutan sudah seharusnya memperhatikan perlindungan hukum bagi para konsumen pengguna jasa pengangkutan, dan hal ini menjadi alasan menarik untuk diteliti lebih lanjut, yang tujuannya untuk mengetahui aspek-aspek hukum perlindungan terhadap para penumpang bus (konsumen) dalam mewujudkan perlindungan konsumen.

\section{B. Metode Penelitian}

Sifat penelitian ini adalah deskriptif, yang dimaksudkan untuk memberikan data yang seteliti mungkin tentang manusia, keadaan atau gejala-gejala lainnya. Penelitian ini menggunakan data sekunder, baik berupa bahan hukum primer, bahan hukum sekunder, maupun bahan hukum tertier, oleh sebab itu dapat disebut penelitian hukum normatif atau penelitian hukum kepustakaan (Soerjono Soekanto dan Sri Mamudji, 2003: 14). Data dikumpulkan dengan menggunakan 
metode studi dokumen, sedangkan analisis terhadap data yang telah terkumpul dilakukan secara yuridis kualitatif, yang hanya difokuskan pada aspek hukum perlindungan terhadap para penumpang bus dalam mewujudkan perlindungan konsumen.

\section{Hasil Penelitian dan Analisis}

\section{Aspek hukum perlindungan konsumen}

Salah satu cara untuk menciptakan ketertiban dalam masyarakat adalah memberikan perlindungan bagi masyarakat dalam melakukan kegiatan ekonomi. Adanya hubungan antara pelaku usaha dan konsumen sering terdapat ketidaksetaraan di antara keduanya. Konsumen biasanya berada dalam posisi yang lemah, sehingga sering terjadi ketidakseimbangan antara pelaku usaha yang merasa mempunyai posisi yang lebih kuat daripada konsumen.

Istilah perlindungan konsumen berkaitan dengan perlindungan hukum, oleh karena itu perlindungan konsumen mengandung aspek hukum. Materi yang mendapatkan perlindungan itu bukan sekedar fisik, melainkan terlebih-lebih hakhaknya bersifat abstrak. Dengan kata lain, perlindungan konsumen sesungguhnya identik dengan perlindungan yang diberikan hukum terhadap hak-hak konsumen (Siregar 2009: 324).

Perlindungan konsumen adalah istilah yang dipakai untuk menggambarkan perlindungan hukum yang diberikan kepada konsumen dalam usahanya untuk memenuhi kebutuhannya dari hal-hal yang dapat merugikan konsumen itu sendiri (Sidabalok 2006: 9). Berbicara perlindungan konsumen berarti mempersoalkan jaminan atau kepastian tentang terpenuhinya hak-hak konsumen.

Perlunya jaminan atau kepastian hukum terhadap hak-hak konsumen, karena didasarkan pada posisi konsumen yang lebih lemah, sehingga ada kecenderungan dari pelaku usaha yang melecehkan hak-hak konsumen. Menurut David Oughton dan John Lowry, sebagaimana dikutip Abdul Halim Barkatullah (2004: 45), dikatakan bahwa posisi konsumen yang lemah ini didasarkan beberapa argumentasi, yaitu: 
a. Dalam masyarakat modern, menawarkan berbagai jenis produk baru dari hasil kemajuan tekhnologi dan manajemen. Barang-barang diproduksi secara masal;

b. Terdapat perubahan-perubahan mendasar dalam pasar konsumen, dimana konsumen sering tidak mendapat posisi tawar untuk melakukan evaluasi yang memadai terhadap produk barang dan jasa yang diterimanya. Konsumen hampir-hampir tidak dapat diharapkan memahami sepenuhnya penggunaan produk-produk canggih yang tersedia;

c. Metode pengiklanan modern melakukan disinformasi kepada konsumen dari pada memberikan informasi secara objektif;

d. Pada dasarnya konsumen berada dalam posisi tawar yang tidak seimbang, karena kesulitan dalam memperoleh informasi yang memadai; dan

e. Gagasan paternalism melatar belakangi lahirnya undang-undang perlindungan hukum bagi konsumen, dimana terdapat rasa tidak percaya terhadap kemampuan konsumen melindungi diri sendiri akibat resiko keuangan yang dapat diperkirakan atau resiko kerugian fisik.

Menurut Troelstrup sebagaimana dikutip Abdul Halim Barkatullah (2004: 98), dikatakan pula bahwa, posisi tawar menawar yang lemah bagi konsumen disebabkan oleh:

a. Terdapat lebih banyak produk, merk, dan cara penjualannya;

b. Daya beli konsumen semakin meningkat;

c. Lebih banyak merk yang beredar di pasaran, sehingga belum banyak diketahui oleh semua orang;

d. Model-model produk lebih cepat berubah;

e. Kemudahan transportasi dan komunikasi sehingga membuka akses yang lebih besar kepada bermacam-macam;

f. Iklan yang menyesatkan; dan

g. Wanprestasi oleh pelaku usaha.

Dilatarbelakangi lemahnya posisi tawar menawar dari konsumen, tentunya menyebabkan hukum perlindungan konsumen menjadi penting, dan sebagai bentuk perlindungan bagi konsumen, maka diberlakukanlah Undang-undang Nomor 8 Tahun 1999 tentang Perlindungan Konsumen (UU No. 8 Tahun 1999). Perlunya peraturan ini, karena perlindungan konsumen merupakan masalah bagi semua bangsa di dunia. Mewujudkan perlindungan konsumen adalah mewujudkan hubungan berbagai dimensi yang satu sama lain mempunyai keterikatan dan saling ketergantungan antara konsumen, dan pemerintah (Wahyu Sasongko 2007: 176).

Selain UU No. 8 Tahun 1999, maka yang dapat dijadikan dasar hukum bagi perlindungan hukum bagi konsumen di Indonesia, adalah: 
a. Undang-undang Nomor 5 Tahun 1999 tentang Larangan Praktek Monopoli dan Persaingan Usaha Usaha Tidak Sehat.

b. Undang-undang Nomor 30 Tahun 1999 tentang Arbitrase dan Alternatif Penyelesian Sengketa.

c. Peraturan Pemerintah Nomor 58 Tahun 2001 tentang Pembinaan Pengawasan dan Penyelenggaraan Perlindungan Konsumen

d. Surat Edaran Dirjen Perdagangan Dalam Negeri Nomor: 235/DJPDN/VII/ 2001 tentang Penangan Pengaduan Konsumen yang ditujukan kepada Seluruh Dinas Perindustrian dan Perdagangan Propinsi/Kabupaten/Kota.

e. Surat Edaran Direktur Jenderal Perdagangan Dalam Negeri Nomor: 795/ DJPDN/SE/12/2005 tentang Pedoman Pelayanan Pengaduan Konsumen.

Berdasarkan Pasal 1 angka 1 UU No. 8 Tahun 1999, disebutkan bahwa: "Perlindungan konsumen adalah segala upaya yang menjamin adanya kepastian hukum untuk memberi perlindungan kepada konsumen”. Perlindungan konsumen (consumer protection) merupakan salah satu sisi dari korelasi antara lapangan perekonomian dengan lapangan etika. Dalam kegiatan bisnis terdapat hubungan yang saling membutuhkan antara pelaku usaha dan konsumen. Kepentingan pelaku usaha adalah memperoleh laba (profit) dari transaksi dengan konsumen, sedangkan kepentingan konsumen adalah memperoleh kepuasan melalui pemenuhan kebutuhannya terhadap produk tertentu. Dalam hubungan yang demikian seringkali terdapat ketidaksetaraan antara keduanya. Konsumen biasanya berada dalam posisi yang lemah dan karenanya dapat menjadi sasaran eksploitasi dari pelaku usaha yang secara sosial dan ekonomi mempunyai posisi yang kuat (Rachman. www.gustinkartikarachman.blogspot.com. diakses pada tanggal 12 Maret 2016).

Selanjutnya dalam Pasal 2 UU No. 8 Tahun 1999, ditentukan bahwa: "perlindungan konsumen berasaskan manfaat, keadilan, keseimbangan, keamanan, dan keselamatan konsumen serta kepastian hukum", dan dalam penjelasan Pasal 2 UU No. 8 Tahun 1999, disebutkan bahwa perlindungan konsumen diselenggarakan sebagai usaha berdasarkan 5 (lima) asas yang relevan dalam pembangunan nasional, yaitu: 
a. Asas manfaat dimaksudkan utnuk menagamanatkan bahwa segala upaya dalam penyelenggaraan perlindungan konsumen harus memberi manfaat sebesar-besarnya bagi kepentingan konsumen dan pelaku usaha secara keseluruhan.

b. Asas keadilan dimaksudkan agar partisipasi seluruh rakyat dapat diwujudkan secara maksimal dan memberikan kesempatan kepada konsumen dan pelaku usaha untuk memperoleh haknya dan melaksanakan kewajibannya secara adil.

c. Asas keseimbangan dimaksudkan untuk memberikan keseimbangan antar kepentingan konsumen, pelaku usaha dan pemerintah dalam arti materiil maupun spiritual.

d. Asas keamanan dan keselamatan konsumen dimaksudkan untuk memberikan jaminan atas keamanan dan keselamatan kepada konsumen dalam penggunaan, pemakaian, dan pemanfaatan barang dan/atau jasa yang dikonsumsi atau digunakan.

e. Asas kepastian hukum dimaksudkan agar baik pelaku usaha maupun konsumen menaati hukum dan memperoleh keadilan dalam penyelenggaraan perlindungan konsumen, serta negara menjamin kepastian hukum.

Tujuan perlindungan konsumen sebagaimana yang diamanatkan Pasal 3

UU No. 8 Tahun 1999, adalah:

a. Meningkatkan kesadaran, kemampuan, dan kemandirian konsumen untuk melindungi diri.

b. Mengangkat harkat dan martabat konsumen dengan cara menghindarkannya dari akses negatif pemakaian barang dan/atau jasa.

c. Meningkatkan pemberdayaan konsumen dalam memilih, menentukan, dan menuntut hak-haknya sebagai konsumen.

d. Menciptakan sistem perlindungan konsumen yang mengandung unsur kepastian hukum dan keterbukaan informasi serta akses untuk mendapatkan informasi.

e. Menumbuhkan kesadaran pelaku usaha mengenai pentingnya perlindungan konsumen sehingga tumbuh sikap yang jujur dan bertanggungjawab dalam berusaha. 
f. Meningkatkan kualitas barang dan/atau jasa yang menjamin kelangsungan usaha produksi barang dan/atau jasa, kesehatan, kenyamanan. keamanan, dan keselamatan konsumen.

Perlindungan konsumen diberikan karena didasarkan pada 4 (empat) alasan, yaitu:

a. Melindungi konsumen sama artinya dengan melindungi seluruh bangsa sebagaimana yang diamanatkan oleh tujuan pembangunan nasional menurut pembukaan Undang Undang Dasar 1945.

b. Melindungi konsumen perlu untuk melahirkan manusia-manusia yang sehat rohani dan jasmani sebagai pelaku-pelaku pembangunan, yang berarti juga untuk kesinambungan pembangunan nasional.

c. Melindungi konsumen perlu untuk menjamin sumber dana pembangunan yang bersumber dari masyarakat.

\section{Hak-hak dan kewajiban konsumen}

Kata konsumen berasal dari bahasa Inggris yakni consumer, yang artinya pemakai (Echols dan Shadily 1996: 142) atau dalam bahasa Belanda "consument", artinya juga konsumen. Konsumen secara bahasa artinya pemakai barang hasil produksi, seperti bahan pakaian dan makanan (Tim Redaksi 2008: 728). Konsumen secara harfiah adalah orang yang memerlukan, membelanjakan atau menggunakan; pemakai atau pembutuh (Siahaan 2005: 23).

Konsumen umumnya diartikan sebagai pemakai terakhir dari produk yang diserahkan kepada mereka oleh pengusaha, yaitu setiap orang yang mendapatkan barang untuk dipakai dan tidak untuk diperdagangkan atau diperjualbelikan lagi. (Siahaan 2005: 172). Pengertian konsumen dalam arti umum adalah pemakai, pengguna dan atau jasa untuk tujuan tertentu (Ningrum. www.repository.undip. ac.id, diakses pada tanggal 12 Maret 2016).

Berdasarkan Pasal 1 angka 2 UU No. 8 Tahun 1999, disebutkan bahwa konsumen adalah setiap orang pemakai barang dan/atau jasa yang tersedia dalam masyarakat, baik bagi kepentingan diri sendiri, keluarga, orang lain, maupun makhluk hidup lain dan tidak untuk diperdagangkan. Dalam penjelasan Pasal 1 angka 2 tersebut disebutkan bahwa konsumen yang dimaksud adalah konsumen 
akhir yang dikenal dalam kepustakaan ekonomi. Dengan demikian, dapat dikatakan bahwa semua orang adalah konsumen karena membutuhkan barang dan jasa untuk mempertahankan hidupnya sendiri, keluarganya, ataupun untuk memelihara atau merawat harta bendanya.

Menurut Az. Nasution, sebagaimana dikutip Trias Palupi Kurnianingrum (www.repository.undip.ac.id. diakses pada tanggal 12 Maret 2016), dikatakan bahwa orang yang dimaksud di atas adalah orang alami bukan badan hukum, sebab yang memakai, menggunakan dan atau memanfaatkan barang dan atau jasa untuk kepentingan diri sendiri, keluarga, orang lain maupun makhluk hidup lain dan tidak untuk diperdagangkan hanyalah orang alami atau manusia. Perlindungan konsumen pada dasarnya untuk melihat terpenuhi atau tidaknya hak-hak konsumen. Hak adalah sesuatu yang benar, kepunyaan, milik, kekuasaan untuk melakukan sesuatu karena telah ditentukan oleh undang-undang atau peraturan lain, kekuasaan yang benar untuk menuntut sesuatu atau kekuasaan yang benar atas sesuatu (Sudarsono 2012: 154).

Menurut Shidarta (2004: 16), dikatakan bahwa secara umum dikenal adanya 4 (empat) hak dasar konsumen yaitu: "hak untuk mendapatkan kemanan (the right to safety), hak untuk mendapatkan informasi (the right to be informed), hak unuk memilih (the right to choose), dan akhirnya hak untuk didengar (the right to be heard). Berdasarkan Pasal 4 UU No. 8 Tahun 1999, disebutkan bahwa hak konsumen yang mendapat jaminan dan perlindungan dari hukum, yaitu:

a. Hak atas kenyamanan, keamanan dan keselamtan dalam mengkonsumsi barang dan/atau jasa;

b. Hak untuk memilih barang dan/atau jasa serta mendapatkan barang dan/jasa tersebut sesuai dengan nilai tukar dan kondisi serta jaminan yang dijanjikan;

c. Hak atas informasi yang benar, jelas, dan jujur mengenai kondisi dan jaminan barang dan/atau jasa;

d. Hak untuk didengar pendapat dan keluhannya atas barang dan / atau jasa yang digunakan;

e. Hak untuk mendapatkan advokasi, perlindungan dan upaya penyelesaian sengketa perlindungan konsumen secara patut; 
f. Hak untuk mendapatkan pembinaan dan pendidikan konsumen;

g. Hak untuk diperlakukan atau dilayani secara benar dan jujur serta tidak diskriminatif;

h. Hak untuk mendapatkan kompensasi, ganti rugi dan/atau penggantian, apabila barang dan/atau jasa yang diterima tidak sesuai dengan perjanjian atau tidak sebagaimana mestinya;

i. Hak-hak yang diatur dalam ketentuan peraturan perundang-undangan lainnya.

Memperhatikan 9 (sembilan) butir hak konsumen yang diuraikan di atas, terlihat bahwa masalah kenyamanan, keamanan, dan keselamatan konsumen merupakan hal yang paling pokok dan utama dalam perlindungan konsumen. Hak-hak konsumen tersebut merupakan penjabaran dari pasal-pasal yang bercirikan Negara Kesejahteraan, yaitu Pasal 27 ayat (2) dan Pasal 33 Undang Undang Dasar Negara Republik Indonesia Tahun 1945.

Selain hak-hak konsumen, maka dalam Pasal 5 UU No. 8 Tahun 1999 diatur pula tentang kewajiban konsumen, yaitu:

a. Membaca atau mengikuti petunjuk informasi dan prosedur pemakaian atau pemanfaatan barang dan/atau jasa demi keamanan dan keselamatan;

b. Beritikad baik dalam melakukan transaksi pembelian barang dan/atau jasa;

c. Membayar sesuai dengan nilai tukar yang disepakati;

d. Mengikuti upaya penyelesaian hukum sengketa perlindungan konsumen secara patut.

Penjabaran Pasal 5 UU No. 8 Tahun 1999 tersebut di atas, sebenarnya dimaksudkan agar konsumen sendiri dapat memperoleh hasil yang optimal atas perlindungan dan/atau kepastian hukum bagi dirinya, karena perlindungan konsumen bertujuan untuk melindungi konsumen dan hak-haknya secara hukum dari pelanggaran-pelanggaran dan penyalahgunaan hak. Dalam hal ini, perlindungan konsumen mempunyai bentuk dan format khusus dan tersendiri. Bentuk ini berasal dari bentuk perlindungan konsumen secara umum yang menjadi landasannya untuk semua bidang hukum konsumen, karena pada dasarnya semua transaksi itu sama, ada produsen ada pula konsumen, yang membedakannya hanyalah dalam bidang hukum konsumen apa transaksi tersebut berlangsung. 
Perlindungan konsumen merupakan bagian tak terpisahkan dari kegiatan bisnis yang sehat. Dalam kegiatan bisnis yang sehat terdapat keseimbangan perlindungan hukum antara konsumen dengan produsen. Tidak adanya perlindungan yang seimbang menyebabkan konsumen berada pada posisi yang lemah. Lebih-lebih jika produk yang dihasilkan oleh produsen merupakan jenis produk yang terbatas, produsen dapat menyalahgunakan posisinya yang monopolistis tersebut. Hal itu tentu saja akan merugikan konsumen (Miru 2011: 1).

\section{Perlindungan hukum terhadap penumpang akibat terjadinya kecelakaan bus}

Konsep hukum sangat dibutuhkan apabila mempelajari hukum. Konsep hukum pada dasarnya adalah batasan tentang suatu istilah tertentu. Tiap istilah ditetapkan arti dan batasan maknanya setajam dan sejelas mungkin yang dirumuskan dalam suatu definisi dan digunakan secara konsisten. Konsep yuridis (legal concept), yaitu konsep konstruktif dan sistematis yang digunakan untuk memahami suatu aturan hukum atau sistem aturan hukum.

Menurut Subekti sebagaimana dikutip oleh C.S.T. Kansil (2002: 14) mengatakan bahwa hukum itu mengabdi pada tujuan negara, yang dalam pokoknya ialah mendatangkan kemakmuran dan kebahagiaan pada rakyatnya. Tujuan negara tersebut dengan menyelenggarakan "keadilan" dan "ketertiban", syarat-syarat yang pokok untuk mendatangkan kemakmuran dan kebahagiaan. Salah satu tujuan hukum adalah mewujudkan keadilan sebagai syarat untuk mendatangkan kemakmuran dan kebahagiaan bagi masyarakat. Berawal dari statemen ini, maka pandangan awal tentang terwujudnya tujuan hukum adalah penegakan hukum.

Menurut Fitzgerald, sebagaimana dikutip Rahardjo (2000: 53), dikatakan bahwa hukum bertujuan mengintegrasikan dam mengkoordinasikan berbagai kepentingan dalam masyrakat karena dalam suatu lalu lintas kepentingan, perlindungan terhadap kepentingan tertentu dapat dilakukan dengan cara membatasi berbagai kepentingan di lain pihak. Kepentingan hukum adalah mengurusi hak dan kepentingan manusia, sehingga hukum memiliki otoritas tertinggi untuk menentukan kepentingan manusia yang perlu diatur dan dilindungi. 
Perlindungan hukum harus melihat tahapan yakni perlindungan hukum lahir dari suatu ketentuan hukum dan segala peraturan hukum yang diberikan oleh masyarakat yang pada dasarnya merupkan kesepakatan masyarakat tersebut untuk mengatur hubungan prilaku antara angota-anggota masyarakat dan antara perseorangan dengan pemerintah yang dianggap mewakili kepentingan masyarakat. Menurut Satjipto Rahardjo (2000: 54), perlindungan hukum ialah memberikan pengayoman terhadap hak asasi manusia (HAM) yang dirugikan orang lain dan perlindungan itu diberikan kepada masyarakat agar dapat menikmati semua hakhak yang diberikan oleh hukum. Frasa perlindungan hukum dalam bahasa Inggris adalah "legal protection" dalam bahasa Belanda "rechtsbecherming". Kedua istilah tersebut juga mengandung konsep atau pengertian hukum yang berbeda untuk memberi makna sesungguhnya dari "Perlindungan Hukum", sedangkan Menurut Salim HS dan Erlies Setiana Nurbani perlindungan hukum adalah upaya atau bentuk pelayanan yang diberikan oleh hukum kepada subjek hukum serta halhal yang menjadi objek yang dilindungi (Salim dan Nurbani 2013: 262).

Pendapat lain menurut Andi Hamzah, sebagaimana dikutip Darwis (www. irwankaimoto.blogspot.com. diakses pada tanggal 12 Maret 2016), perlindungan hukum dimaknai sebagai daya upaya yang dilakukan secara sadar oleh setiap orang maupun lembaga pemerintah, swasta yang bertujuan mengusahakan pengamanan, penguasaan dan pemenuhan kesejahteraan hidup sesuai dengan hakhak asasi yang ada. Makna tersebut tidak terlepas dari fungsi hukum itu sendiri, yaitu untuk melindungi kepentingan manusia. Dengan kata lain hukum memberikan perlindungan kepada manusia dalam memenuhi berbagai macam kepentingannya, dengan syarat manusia juga harus melindungi kepentingan orang lain.

Menurut Philipus M. Hadjon (www.statushukum.com. diakses pada tanggal 12 Maret 2016), dikatakan bahwa perlindungan hukum bagi rakyat meliputi 2 (dua) hal, yakni:

a. Perlindungan hukum preventif, yakni bentuk perlindungan hukum dimana kepada rakyat diberi kesempatan untuk mengajukan keberatan atau pendapatnya sebelum suatu keputusan pemerintah mendapat bentuk yang definitif; dan 
b. Perlindungan hukum represif, yakni bentuk perlindungan hukum dimana lebih ditujukan dalam penyelesian sengketa.

Perlindungan hukum yang preventif merupakan perlindungan hukum yang sifatnya pencegahan. Perlindungan memberikan kesempatan kepada rakyat untuk mengajukan keberatan (inspraak) atas pendapatnya sebelum suatu keputusan pemerintahan mendapat bentuk definitif. Perlindungan hukum preventif ini bertujuan untuk mencegah terjadinya sengketa dan sangat besar artinya bagi tindak pemerintah yang didasarkan pada kebebasan bertindak. Adanya perlindungan hukum yang preventif ini mendorong pemerintah untuk berhati-hati dalam mengambil keputusan yang berkaitan dengan asas freies ermessen, dan rakyat dapat mengajukan keberatan atau dimintai pendapatnya mengenai rencana keputusan tersebut (Salim dan Nurbani 2013: 264).

Perlindungan hukum yang represif berfungsi untuk menyelesaikan apabila terjadi sengketa. Indonesia dewasa ini terdapat berbagai badan yang secara parsial menangani perlindungan hukum bagi rakyat, yang dikelompokkan menjadi 2 (dua) badan, yaitu (Salim dan Nurbani 2013: 262):

1. Pengadilan dalam lingkup Peradilan Umum; dan

2. Institusi Pemerintah yang merupakan lembaga banding administrasi.

Terkait dengan konsep perlindungan hukum yang diuraikan di atas, maka penumpang bus sebagai konsumen tetap memiliki hak-hak yang mesti dilindungi oleh negara dan pihak perusahaan pengangkutan. Berdasarkan Pasal 1 ayat (25) UU No. 22 Tahun 2009, yang disebut penumpang adalah setiap orang yang berada di kendaraan selain pengemudi dan awak kenderaan. Dengan mengikatkan diri setelah membayar uang atau tiket angkutan umum sebagai kontraprestasi dalam perjanjian pengangkutan maka seseorang telah sah sebagai penumpang alat angkutan penumpang umum yang apabila mengalami kecelakaan diri, yang diakibatkan oleh penggunaan alat angkutan umum, selama penumpang yang bersangkutan berada dalam angkutan tersebut, yaitu saat naik dari tempat pemberangkatan sampai turun di tempat tujuan. Tiket penumpang adalah tanda bukti bahwa seseorang telah membayar uang angkutan dan akibatnya berhak naik angkutan sebagai penumpang. Tiket penumpang juga menjadi tanda bukti telah 
ditutupnya perjanjian angkutan antara pengangkut dan penumpang, sehingga penumpang adalah salah satu pihak.

Berlakunya UU No. 22 Tahun 2009 diharapkan dapat membantu mewujudkan kepastian hukum bagi pihak-pihak yang terkait dengan penyelenggaraan jasa angkutan, baik itu pengusaha angkutan, pekerja (sopir/pengemudi) serta penumpang. Secara operasional kegiatan penyelenggaraan pengangkutan dilakukan oleh pengemudi atau sopir angkutan dimana pengemudi merupakan pihak yang mengikatkan diri untuk menjalankan kegiatan pengangkutan atas perintah pengusaha angkutan atau pengangkut. Pengemudi dalam menjalankan tugasnya mempunyai tanggung jawab untuk dapat melaksanakan kewajibannya yaitu mengangkut penumpang sampai pada tempat tujuan yang telah disepakati dengan selamat, artinya dalam proses pemindahan tersebut dari satu tempat ke tempat tujuan dapat berlangsung tanpa hambatan dan penumpang dalam keadaan sehat, tidak mengalami bahaya, luka, sakit maupun meninggal dunia. Sehingga tujuan pengangkutan dapat terlaksana dengan lancar dan sesuai dengan nilai guna masyarakat.

Dalam UU No. 22 Tahun 2009 penumpang dikenal dengan istilah pengguna jasa, yang di dalam Pasal 1 angka 21, disebutkan bahwa perusahaan angkutan umum adalah badan hukum yang menggunakan jasa perusahaan angkutan umum. Dengan mengikatkan diri setelah membayar uang atau tiket angkutan umum sebagai kontraprestasi dalam perjanjian pengangkutan maka seseorang telah sah sebagai penumpang alat angkutan penumpang umum yang apabila mengalami kecelakaan diri, yang diakibatkan oleh penggunaan alat angkutan umum, selama penumpang yang bersangkutan berada dalam angkutan tersebut, yaitu saat naik dari tempat pemberangkatan sampai turun di tempat tujuan. Tiket penumpang adalah tanda bukti bahwa seseorang telah membayar uang angkutan dan akibatnya berhak naik pesawat udara sebagai penumpang.

Perlindungan hukum bagi penumpang angkutan umum di darat telah di atur dalam UU No. 22 Tahun 2009. Peraturan ini yang menjadi pedoman untuk melindungi kepentingan penumpang jika haknya ada yang dilanggar oleh penyedia jasa angkutan umum. Seperti yang diatur pada Pasal 234 ayat (1) UU 
No. 22 Tahun 2009, yang secara garis besar menjelaskan bahwa pihak penyedia jasa angkutan umum wajib bertanggung jawab atas kerugian yang dialami oleh penumpang yang diakibatkan oleh kelalaian pengemudi.

Pasal 234 ayat (1) UU No. 22 Tahun 2009, tersebut mengisyarakan kepada pihak penyedia angkutan umum tidak hanya menyediakan layanan yang nyaman, aman berupa fasilitas yang layak bagi penumpang sebagai konsumen, tetapi juga harus memberikan edukasi terhadap para supirnya agar berperilaku baik dalam menjakankan tugas yaitu mengantar penumpang sampai ke tujuan dengan selamat. Pemilik jasa angkutan umum tidak hanya mementingkan keuntungan semata yang diperoleh dari tiket penumpang tapi juga harus memikirkan keselamatan penumpang. Berdasarkan hal itu para supir yang terdidik dengan disiplin kerja yang baik serta mengetahui regulasi tentang aturan hukum selama di jalan, mutlak harus ada dalam setiap jasa angkutan umum.

Perlindungan hukum bagi penumpang adalah suatu masalah yang besar dengan persaingan global yang terus berkembang sehingga perlindungan hukum sangat dibutuhkan dalam persaingan global. Pasal 192 ayat (1) UU No. 22 Tahun 2009 menjelaskan bahwa perusahaan angkutan umum bertanggung jawab atas kerugian yang diderita oleh penumpang yang meninggal dunia atau luka akibat penyelenggaraan angkutan, kecuali disebabkan oleh suatu kejadian yang tidak dapat dicegah atau dihindari atau karena kesalahan penumpang.

Dilihat dari aspek perlindungan hukum bagi konsumen jasa angkutan, keadaan demikian sangat tidak ideal dan dalam praktik merugikan bagi konsumen, karena pada tiap kecelakaan alat angkutan darat tidak penah terdengar dipermasalahkannya tanggung jawab pengusaha kendaraan angkutan umum. Pihak perusahaan angkutan umum wajib bertanggungjawab memberikan hak-hak kepada konsumen jika terjadi hal-hal yang merugikan konsumen tersebut.

Tanggung jawab pada hakikatnya terdiri dari dua aspek, yaitu tanggung jawab yang bersifat kewajiban yang harus dilaksanakan sebaik-baiknya (responsibility), yaitu tanggung jawab terhadap setiap kerugian yang diderita oleh penumpang dan tanggung jawab ganti rugi (liability), yaitu terkait dengan program asuransi kecelakaan lalu lintas dan angkutan jalan merupakan suatu hal 
yang tidak boleh ditawar-tawar. Essensi program asuransi tersebut sebagai suatu asuransi wajib/sosial dan asuransi tanggung jawab (Nasution. www.portalgaruda. org. diakses pada tanggal 12 Maret 2016).

Perusahaan pengangkutan umum bertanggung jawab atas kerugian yang diderita oleh penumpang, pengirim atau pihak ketiga karena kelalaiannya dalam melaksanakan pelayanan pengangkutan. Selama pelaksanaan pengangkutan, keselamatan penumpang atau barang yang diangkut pada dasarnya berada dalam tanggung jawab perusahaan pengangkutan umum. Oleh karena itu, sudah sepatutnya apabila kepada perusahaan pengangkutan umum dibebankan tanggung jawab terhadap setiap kerugian yang diderita oleh penumpang atau pengirim, yang timbul karena pengangkutan yang dilakukannya (Pasal 234 UU No. 22 Tahun 2009). Pengemudi Kendaraan Bermotor Umum dapat menurunkan penumpang dan/atau barang yang diangkut pada tempat pemberhentian terdekat jika Penumpang dan/atau barang yang diangkut dapat membahayakan keamanan dan keselamatan angkutan (Pasal 190 UU No. 22 Tahun 2009).

Penyelenggaraan angkutan penumpang bus umum yang aman, selamat, dan tertib, juga merupakan bagian penting dan menjadi salah satu tujuan utama dalam suatu penyelenggaraan angkutan. Untuk memenuhi tujuan utama tersebut, maka setiap penyelenggaraan angkutan penumpang bus umum wajib memenuhi standar pelayanan minimal yang meliputi: (a) keamanan; (b) keselamatan; (c) kenyamanan; (d) keterjangkauan; (e) kesetaraan; dan (f) keteraturan, seperti yang ditentukan dalam Pasal 141 ayat (1) UU No. 22 Tahun 2009, dan hal ini adalah sebagai hak penumpang. Perlindungan hukum bagi penumpang angkutan umum di darat telah di atur dalam UU No. 22 Tahun 2009, yang menjadi pedoman untuk melindungi kepentingan penumpang jika haknya ada yang dilanggar oleh penyedia jasa angkutan umum. Seperti pada Pasal 234 ayat (1) menentukan bahwa pihak penyedia jasa angkutan umum wajib bertanggung jawab atas kerugian yang dialami oleh penumpang yang diakibatkan oleh kelalaian pengemudi.

Tiket penumpang merupakan syarat dalam perjanjian pengangkutan darat, tetapi bukan merupakan syarat mutlak, sebab tidak adanya tiket penumpang tidak berarti tidak adanya perjanjian pengangkutan. Penumpang angkutan umum yang 
tidak mendapatkan tiket, tetap harus mendapat jaminan hukum atas keselamatannya, jika pengangkut tidak dapat melaksanakan kewajibannya dalam pengangkutan orang yakni membawa atau mengangkut penumpang tersebut sampai di tempat tujuan dengan selamat.

Menurut Purwosutjipto, sebagaimana dikutip Apbisma (www.apbisma. blogspot.com. diakses pada tanggal 12 Maret 2016), dikatakan bahwa kewajibankewajiban dari pihak pengangkut adalah:

a. Menyediakan alat pengangkut yang akan digunakan untuk menyelenggarakan pengangkutan.

b. Menjaga keselamatan orang (penumpang) dan/ atau barang yang diangkutnya. Dengan demikian maka sejak pengangkut menguasai orang (penumpang) dan/ atau barang yang akan diangkut, maka sejak saat itulah pihak pengangkut mulai bertanggung jawab (Pasal 1235 KUHPerdata).

c. Kewajiban yang disebutkan dalam Pasal 470 KUHD yang meliputi:

1) Mengusahakan pemeliharaan, perlengkapan atau peranakbuahan alat pengangkutnya;

2) Mengusahakan kesanggupan alat pengangkut itu untuk dipakai menyelenggarakan pengangkutan menurut persetujuan;

3) Memperlakukan dengan baik dan melakukan penjagaan atas muatan yang diangkut; dan

4) Menyerahkan muatan ditempat tujuan sesuai dengan waktu yang telah ditetapkan dalam perjanjian.

Perlindungan hukum bagi penumpang adalah masalah yang besar dengan persaingan global yang terus berkembang sehingga perlindungan hukum sangat dibutuhkan dalam persaingan global, dan perlindungan hukum bagi para penumpang dapat dilakukan dengan cara membuat peraturan yang diperlukan, oleh sebab itu peraturan perundang-undangan yang telah dibuat tersebut harus ditegakkan (by the law enforcement), baik bersifat preventif, represif, maupun curatif.

Mengingat peranan lalu lintas dan angkutan jalan yang menguasai hajat hidup orang banyak, maka penyelenggaraan lalu lintas dan angkutan jalan perlu 
diselenggarakan secara berkesinambungan dan terus ditingkatkan, agar lebih luas daya jangkau dan pelayanannya kepada masyarakat lebih optimal dengan tetap mengutamakan keselamatan para penggunanya. Transportasi jalan yang diselenggarakan harus bertujuan untuk mewujudkan lalu lintas dan angkutan jalan dengan selamat, aman, cepat, lancer, tertib dan teratur, nyaman dan efesien, mampu memadukan moda transportasi lainnya, menjangkau seluruh pelosok wilayah daratan untuk menunjang pemerataan penggerak dan penunjang pembangunan nasional dengan biaya yang terjangkau oleh daya beli masyarakat.

Konsumen angkutan umum bus memiliki hak untuk dilayani secara benar dan layak oleh pelaku usaha. Konsumen juga berhak atas keselamatan dan kenyamanan atas jasa angkutan umum bus yang digunakan, dan untuk menjamin adanya keselamatan tersebut, maka pelayanan harus dengan standar mutu yang baik, maka pelaku usaha harus menggunakan kendaraan yang benar-benar laik jalan untuk mengangkut penumpang. Konsumen juga secara tegas memiliki hak untuk menuntut ganti rugi kepada pelaku usaha jika penumpang atau konsumen, jika penumpang misalnya kerugian akibat kecelakaan lalu lintas atau kerugian lainnya. Konsumen juga memiliki hak untuk mendapatkan ganti rugi jika ia mendapatkan pelayanan yang tidak semestinya.

Pelayanan seperti tersebut di atas sesuai dengan ketentuan Pasal 8 UU No. 8 Tahun 1999, yang melarang pelaku usaha yang memproduksi atau memperdagangkan barang dan atau jasa yang tidak memenuhi atau tidak sesuai dengan standar yang diisyaratkan dan ketentuan peraturan perundang-undangan. Oleh sebab itu, dalam mengoperasikan kendaraan sebagai angkutan umum harus laik jalan. Selain itu, berdasarkan Pasal 15 UU No. 8 Tahun 1999, ditentukan pula bahwa dalam menawarkan barang atau jasanya pelaku usaha juga tidak dibenarkan atau dilarang untuk: (a) tidak menepati pesanan dan atau kesepakatan waktu penyelesaian sesuai dengan yang dijanjikan; dan (b) tidak menepati janji atas suatu pelayanan dan atau prestasi.

Selain itu, jika diperhatikan ketentuan yang terdapat dalam Pasal 188 dan Pasal 234 UU No. 22 Tahun 2009, maka Perusahaan angkutan umum wajib mengganti kerugian yang diderita oleh penumpang atau pengirim barang karena lalai 
dalam melaksanakan pelayanan angkutan. Pengemudi, pemilik kendaraan bermotor, dan/atau perusahaan angkutan umum juga bertanggungjawab atas kerugian yang diderita oleh penumpang dan/atau pihak ketiga karena kelalaian pihak pengemudi.

\section{Simpulan dan Saran}

\section{Simpulan}

Perlindungan hukum terhadap penumpang akibat terjadinya kecelakaan bus telah di atur dalam UU No. 22 tahun 2009, dan peraturan ini menjadi pedoman untuk melindungi kepentingan penumpang jika haknya dilanggar oleh penyedia jasa angkutan umum. Atas dasar ketentuan yang terdapat dalam UU No. 22 Tahun 2009 dan UU No. 8 Tahun 1999, maka pelaku usaha harus bertanggungjawab memberikan ganti rugi yang mungkin diderita konsumen akibat ketidakselamatan penumpang ketika ia menggunakan jasa tersebut, dapat berupa ganti rugi yang dapat berupa pengembalian uang dan atau penggantian barang.

\section{Saran}

Penumpang selaku konsumen jasa angkutan transportasi darat hendaknya lebih pro aktif dalam memperhatikan hak-haknya sebagai konsumen, selain itu pemerintah diharapkan dapat meningkatkan pengawasannya terhadap penyelenggaraan pengangkutan transportasi darat sehingga terjadi keselarasan akan hak dan kewajiban antara penumpang dan perusahaan penyedia jasaangkutan transportasi darat demi terciptanya hubungan yang baik antara penumpang dan pelaku usaha sebagai penyediajasa angkutan serta pemerintah. 


\section{DAFTAR PUSTAKA}

\section{Buku:}

Abdul Halim Barkatullah. 2004. Hukum Pengangkutan Darat dan Udara. Bandung: Sinar Grafika.

Abdulkadir Muhammad. 2008. Hukum Pengangkutan Niaga. Bandung: PT. Citra Aditya Bakti.

Ahmadi Miru. 2011. Prinsip-prinisp Perlindungan Hukum bagi Konsumen di Indonesia. Cetakan Kesatu. Edisi 1. Jakarta: PT RajaGrafindo Persada.

Echols, John M. dan Hassan Shadily. 1996. Kamus Inggris Indonesia An EnglishIndonesian Dictionary. Cetakan Keduapuluhtiga. Jakarta: PT Gramedia.

Janus Sidabalok. 2006. Hukum Perlindungan Konsumen di Indonesia, Bandung: Citra Aditya Bakti.

Kansil, C.S.T. 2002., Pengantar Ilmu Hukum dan Tata Hukum Indonesia. Cetakan Keduabelas. Jakarta: Balai Pustaka.

Salim HS dan Erlies Septiana Nurbani. 2013. Penerapan Teori Hukum pada Penelitian Tesis dan Disertasi. Jakarta: PT RajaGrafindo Persada.

Satjipto Rahardjo. 2000. Ilmu Hukum. Bandung: PT Citra Aditya Bakti.

Shidarta. 2004. Hukum Perlindungan Konsumen. Edisi Revisi. Jakarta: Grasindo.

Siahaan,N.H.T. 2005. Hukum Konsumen Perlindungan Konsumen dan Tanggung Jawab Produk. Jakarta: Panta Rei.

Soerjono Soekanto dan Sri Mamudji. 2003. Penelitian Hukum Normatif, Suatu Tinjauan Singkat. Cetakan Keenam. Jakarta: RadaGrafindo Persada.

Sudarsono. 2012. Kamus Hukum. Cetakan Keenam. Jakarta: Rineka Cipta.

Tim Redaksi Pusat Bahasa. 2008. Kamus Besar Bahasa Indonesia. Cetakan Kesatu. Edisi Keempat. Jakarta: PT Gramedia Pustaka Utama.

Wahyu Sasongko. 2007. Ketentuan-Ketentuan Pokok Perlindungan Konsumen. Bandar Lampung: UNILA.

\section{Jurnal:}

Syahminul Siregar. 2009. "Peranan Pemerintah dalam Melindungi Hak-hak Konsumen Menurut UU Nomor 8 Tahun 1999 tentang Perlindungan Konsumen”. Jurnal Ilmu-ilmu Sosial. Volume 10. Nomor 3 Oktober 2009. 


\section{Internet:}

Anonim. "Perlindungan Hukum". www.statushukum.com. diakses pada tanggal 12 Maret 2016.

Anonim. "Perlindungan Hukum". www.statushukum.com. diakses pada tanggal 12 Maret 2016.

Apbisma. "Perlindungan Hukum terhadap Penumpang Angkutan Umum Pengangkutan Darat". www.apbisma.blogspot.com. diakses pada tanggal 12 Maret 2016.

Gustin Kartika Rachman. "Hukum Perlindungan Konsumen". www.gustinkartika rachman. blogspot.com. diakses pada tanggal 12 Maret 2016.

Irwan Darwis. "Perlindungan dan Penegakan Hukum". www.irwankaimoto. blogspot.com. diakses pada tanggal 12 Maret 2016.

Krisnadi Nasution. "Perlindungan Hukum terhadap Penumpang Bus Umum". www.portalgaruda.org. diakses pada tanggal 12 Maret 2016.

Trias Palupi Kurnianingrum. "Perlindungan Nasabah Kartu Kredit Ditinjau Dari Undang-undang Nomor 8 Tahun 1999 tentang Perlindungan Konsumen”. repository.undip.ac.id. diakses pada tanggal 12 Maret 2016.

\section{Peraturan Perundang-undangan:}

Undang-undang Nomor 8 Tahun 1999 tentang Perlindungan Konsumen

Undang-undang Nomor 22 Tahun 2009 tentang Lalu Lintas dan Angkutan Jalan 


\section{BIODATA PENULIS}

$\begin{array}{ll}\text { Nama } & \text { : Rabiah Z. Harahap, S.H., M.H } \\ \text { Pekerjaan } & \text { : Dosen Fakultas Hukum Universitas Muhammadiyah Sumatera } \\ & \text { Utara } \\ \text { Jabatan } & : \text { Asisten Ahli } \\ \text { Nomor HP } & : \text { 082304106436 } \\ \text { E-mail } & : \text { rabiahharahap@ yahoo.com } \\ \text { Alamat Kantor } & : \text { Jl. Muchtar Basri No. 3 Medan }\end{array}$ 